\title{
Pengembangan Website Pembelajaran Digital pada Perkuliahan Pendidikan IPA Kelas Tinggi
}

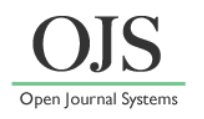

\author{
Rohmani*, Agung Prihatmojo \\ Prodi Pendidikan Guru Sekolah Dasar, Universitas Muhammadiyah Kotabumi, Lampung \\ *Email: rohman.orgos@gmail.com
}

DOI: https://doi.org/10.33369/pendipa.6.1.242-249

\begin{abstract}
This study aims to develop a website digital learning as an alternative learning solution during the COVID19 pandemic in high-class science education lectures. The method used in this study was research and development methods that refer to the stages presented by Sugiyono, (2013). The data collection instruments in this study were in the form of validation sheets, student response questionnaires, and test questions. The subjects in this study were 73 students of the elementary school teacher education program at Muhammadiyah University of Kotabumi. The results of the validated products website of digital learning had a percentage of $79.93 \%$ and declared valid because $61 \%$. The trial results show that the website digital learning is a practical alternative for distance learning during the COVID-19 pandemic with a percentage gain of 90.5 in the very good category. The level of effectiveness of using websites digital learning was reflected in student learning outcomes in the form of pretest and posttest with classical completeness of $86.04 \%$ in the very good category.
\end{abstract}

Keywords: Learning Website; Digital Learning; High Grade Science.

\begin{abstract}
ABSTRAK
Penelitian ini bertujuan untuk mengembangkan website pembelajaran digital sebagai alternatif solusi pembelajaran di masa pandemi covid-19 pada perkuliahan pendidikan IPA kelas tinggi. Metode yang dipakai dalam penelitian ini menggunakan metode penelitian dan pengembangan yang mengacu pada tahapan yang disampaikan oleh Sugiyono, (2013). Instrumen pengumpulan data dalam penelitian ini berupa lembar validasi, lembar angket respon mahasiswa, dan soal tes. Subjek pada penelitian ini adalah 73 mahasiswa program studi pendidikan guru sekolah dasar Universitas Muhammadiyah Kotabumi. Hasil validasi produk website pembelajaran digital dengan persentase sebesar 79,93\% dan dinyatakan valid karena $\geq 61 \%$. Hasil uji coba menunjukkan bahwa website pembelajaran digital merupakan alternatif pilihan yang praktis sebagai pembelajaran jarak jauh di masa pandemi covid-19 dengan perolehan persentase sebesar 90,5 dalam kategori sangat baik. Tingkat keefektifitasan penggunaan website pembelajaran digital tercermin dari hasil belajar mahasiswa berupa pretest dan posttest dengan ketuntasan klasikal sebesar $86,04 \%$ berada pada kategori sangat baik.
\end{abstract}

Kata kunci: Website Pembelajaran; Pembelajaran Digital; IPA Kelas Tinggi.

\section{PENDAHULUAN}

Memasuki era baru sebagai dampak dari pandemi Covid-19 yang saat ini dikenal sebagai era New Normal, proses pendidikan diarahkan pada pembelajaran daring atau pembelajaran online yang kemudian disebut sebagai Pembelajaran Jarak Jauh (PJJ). Pemerintah melalui menteri pendidikan menginstruksikan kepada semua dijenjang pendidikan untuk melaksanakan Pembelajaran Jarak Jauh (PJJ) demi memutus rantai persebaran virus corona. Pembelajaran jarak jauh merupakan pembelajaran yang diterapkan dimasa pandemi (Nugroho, 2012). Pemerintah dalam mendukung sistem Pembelajaran Jarak Jauh menyediakan 
bantuan kuota yang dapat dimanfaatkan oleh pendidik dan peserta didik yang diberikan setiap bulannya. Secara teori seharusnya Pembelajaran Jarak Jauh dapat dilaksanakan dengan baik sesuai harapan dan tujuan pembelajaran karena syarat utama pelaksanaan PJJ yaitu adanya koneksi internet sudah difasilitasi pemerintah.

Pelaksanaan Pembelajaran Jarak Jauh ternyata tidak seperti yang diharapkan (Kahfi, 2020)(Putri \& Dewi, 2019), berbagai kendala dan permasalahan banyak peneliti alami selama perkuliahan 1 semester ditahun akademik 2019/2020. Kendala-kendala yang peneliti alami diantaranya adalah materi perkuliahan tidak dapat dikuasai oleh mahasiswa secara maksimal, tugas-tugas mahasiswa tidak terarsipkan dengan rapi, serta hasil-hasil diskusi mahasiswa tidak terstruktur dengan baik. Sistem PJJ yang peneliti lakukan selama 1 semester lebih banyak memanfaatkan aplikasi sosial media whatsapp dengan membuat grup diskusi daripada menggunakan aplikasi video converence seperti zoom meeting. Sistem perkuliahan menggunakan aplikasi whatsapp tersebut berdasarkan kesepakatan dengan mahasiswa karena berbagai pertimbangan terkait kondisi tempat tinggal mahasiswa. Perkuliahan menggunakan aplikasi zoom meeting yang di tawarkan oleh peneliti hanya berjalan beberapa kali pertemuan diawal karena banyak keluhan dari mahasiswa sehingga terbentuk kesepakatan perkuliahan dengan menggunakan fasilitas grup whatsapp.

Permasalahan materi perkuliahan yang tidak dapat dikuasai secara maksimal oleh mahasiswa disebabkan karena tidak terarsipkannya materimateri perkuliahan yang diberikan oleh peneliti melalui grup whatsapp sehingga saat ujian tengah semester maupun ujian akhir semester hasilnya tidak maksimal. Materi yang dikirim peneliti digrup whatsapp akan tertimpa chat balasan dari mahasiswa sehingga pada saat pertemuan-pertemuan berikutnya mahasiswa kesulitan menemukan materi yang telah dikirim sebelumnya. Permasalahan perkuliahan terkait pengarsipan tugas-tugas mahasiswa yang tidak rapi dikarenakan tugas mahasiswa yang dikirim ke whatsapp melalui chat pribadi mengakibatkan kinerja Hp dosen menjadi tidak optimal sehingga mengharuskan chat yang berisi tugas mahasiswa harus dibersihkan. Permasalahan perkuliahan yang lain terkait hasil diskusi mahasiswa setiap pertemuan tidak terstruktur juga dikarenakan chat hasil diskusi baik berupa voice note maupun dalam bentuk pesan teks akan tertimpa oleh pesan pada pertemuan-pertemuan berikutnya sehingga sulit untuk direview.

Pembelajaran dengan memanfaatkan teknologi telah dilakukan oleh peneliti terdahulu (Husaini, 2017; Komalasari, 2020; Rahmawati, 2008). Komalasari mengungkapkan bahwa teknologi dimanfaatkan salah satunya untuk pembelajaran online. Pembelajaran online dapat berupa membaca materi secara online, menonton video penjelasan dan lain sebagainya (Belawati, 2019). Materi yang dapat diakses secara online tersimpan dalam sebuah website yang databasenya tersimpan dalam hosting. Agar materi dapat diakses dengan mudah oleh pengguna maka harus di rancang sebaik mungkin (Bakri et al., 2016). Keunggulan pembelajaran berbasis website salah satu diantaranya adalah materi yang disajikan dapat beragam dan bervariasi (Nur, 2017) sehingga peserta didik akan memiliki banyak kesempatan dalam memilih materi yang disukai.

Materi pembelajaran yang dapat diakses secara online oleh mahasiswa dalam bentuk digital sehingga mahasiswa tidak membawa buku yang tebal saat hendak mau belajar. Kelebihan bahan ajar digital diantaranya mudah diakses dan tidak memerlukan ruang penyimpanan khusus (Faisal et al., 2020). Berdasarkan beberapa masalah dan potensi yang ada, maka dilakukan penelitian terkait pengembangan website pembelajaran digital untuk penunjang perkuliahan.

\section{METODE PENELITIAN}

Purwanto, (2016) mendefinisikan metode penelitian sebagai "cara ilmiah untuk mendapatkan data dengan tujuan dan kegunaan tertentu". Pengembangan website pembelajaran digital ini menggunakan metode penelitian dan pengembangan. Validator sebagai Ahli materi 2 orang, ahli media 2 orang dan praktisi 2 orang. Jumlah mahasiswa yang terlibat dalam penelitian ini berjumlah 73 mahasiswa.

Langkah-langkah metode Penelitian dan pengembangan dalam penelitian ini 
mengadopsi Langkah penelitian dan pengembangan Sugiyono, (2016). Instrumen penelitian yang digunakan berupa lembar angket respon mahasiswa, lembar penilaian validasi ahli, serta soal tes. Lembar angket validasi diberikan kepada validator dengan penilaian menggunakan skala likert yang dinilai dengan lima indikator. Soal tes terkait materi perkuliahan pendidikan IPA kelas tinggi berjumlah 30 soal dengan 5 pilihan yang diberikan kepada mahasiswa uji coba produk.

Angket respon diberikan kepada mahasiswa dengan Skala Guttman yang didalamnya terdapat 2 jenis pernyataan, berupa pernyataan negative dan positif. Analisis data menggunakan tiga teknik analisis berupa uji kevalidan, uji kepraktisan, serta uji keefektifan.

1. Uji kevalidan

Untuk mengetahui tingkat kevalidan dari produk hasil pengembangan, digunakan rumus perhitungan persentase nilai kevalidan sebagai berikut.

$$
P(\%)=\frac{\sum \text { skor hasil pengumpulan data }}{\text { skor kriterium }} \times 100 \%
$$

Website pembelajaran digital dikatakan valid apabila persentasenya $\geq 61 \%$ (Riduwan, 2011).

2. Uji kepraktisan

Untuk mengetahui tingkat kepraktisan produk hasil pengembangan, digunakan rumus perhitungan persentase angket respon mahasiswa berdasarkan sebagai berikut.

$P=\frac{\text { Jumlah Jawaban ya }}{\text { Jumlah jawaban ya }} \times 100 \%$

Website pembelajaran digital dikatakan telah menjadi website pembelajaran digital yang praktis jika hasil rata-rata persentase yang menjawab "Ya" $\geq 61 \%$. (Riduwan, 2011)
3. Uji keefektifan

Untuk menguji keefektifan dari produk hasil pengembangan, dihitung dengan menggunakan program SPSS berupa Uji normalitas serta uji t berpasangan dengan taraf kepercayaan 95\%. Ketuntasan hasil belajar mahasiswa dilihat dari perhitungan ketuntasan klasikal (KK) menggunakan rumus:

$$
K K=\frac{\sum \text { Tuntas }}{\sum \text { Tidak tuntas }} \times 100 \%
$$

Ketuntasan klasikal dapat dicapai jika persentase siswa yang telah mencapai ketuntasan $\geq 80 \%$ (Riduwan, 2011).

\section{HASIL DAN PEMBAHASAN}

Penelitian ini menghasilkan produk berupa website pembelajaran digital untuk perkuliahan Pendidikan IPA kelas tinggi di Universitas Muhammadiyah Kotabumi. Adapun hasil dari masing-masing tahapan dijelaskan sebagai berikut.

1. Hasil Tahap Temuan Potensi dan Masalah

Tahap awal dari penelitian menghasil temuan berupa potensi dan masalah yang diperoleh dari pengamatan terhadap perkuliahan pada masa awal pandemi covid-19. Masalah yang ada yaitu Pelaksanaan pembelajaran jarak jauh (PJJ) selama 1 semester ditahun akademik 2019/2020 terdapat beberapa kendala atau permasalahan dalam proses perkuliahan. Terdapat 3 permasalahan utama yang dalami peneliti dalam pelaksanaan PJJ yaitu 1) materi perkuliahan sulit dikuasai oleh mahasiswa; 2) kesulitan dalam mengarsipkan tugas-tugas mahasiswa; serta 3) tidak ter koordinir hasil-hasil diskusi mahasiswa dengan baik. Berdasarkan permasalahan tersebut, perlu dicarikan alternatif pemecahan masalah yang dapat dijadikan sebagai solusi pembelajaran dimasa pandemi covid-19 maupun untuk 
sistem pembelajaran jarak jauh di luar kondisi covid-19.

\section{Hasil Tahap Pengumpulan Informasi}

Hasil temuan potensi terhadap masalah, selanjutnya dilakukan penggalian informasi lebih lanjut guna menetapkan bentuk pembelajaran yang mampu menjembatani keterbatasan yang ada. Hasil pengumpulan informasi bahwa setiap mahasiswa memiliki fasilitas teknologi yang berupa perangkat ponsel pintar yang mampu mengakses informasi melalui internet. Informasi dijadikan pijakan dalam menjadikan pembelajaran digital sebagai alternatif bagi dosen selama proses perkuliahan. Kemudahan mengakses informasi memalui internet merupakan produk hasil dari teknologi informasi dan komunikasi yang sangat mendominasi dimasa pandemi covid19 (Komalasari, 2020). Pembelajaran online dengan memanfaatkan teknologi world wide website (www) memainkan peran penting dalam perkembangan e-learning yang cepat (John, 2020).

\section{Hasil Tahap Desain Produk}

Hasil pengumpulan informasi dijadikan patokan dalam perencanaan desain produk. Tahap ini menghasilkan tahapan-tahapan yang meliputi desain website pembelajaran digital, perencanaan layout website, perencanaan bentuk materi digital, serta tataletak tombol menu dalam website pembelajaran digital. Langkah berikutnya setelah tahap awal yaitu tahap pengembangan produk yang meliputi pengembangan desain layout website pembelajaran digital, penyusunan urutan materi digital, serta pembuatan tombol menu pada website pembelajaran digital. Berikut penjelasan masing-masing tahapan tersebu.

a. Hasil tahap perencanaan

Hasil dari pada tahap perencanaan website pembelajaran digital adalah berupa desain dalam bentuk layout website pembelajaran digital pada pembelajaran IPA kelas tinggi. Berikut hasil skema bagan tahap perencanaan template media (Gambar 1).

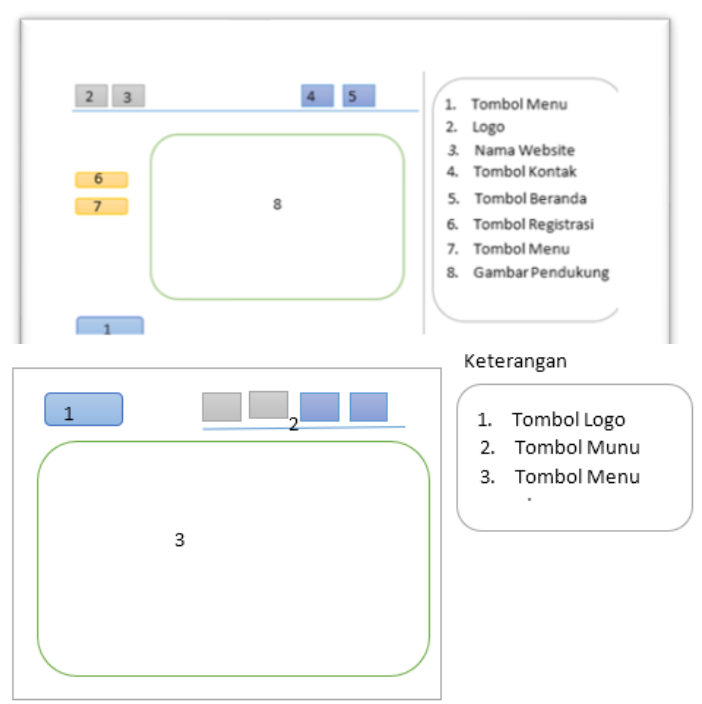

Gambar 1. template menu website

b. Hasil tahap pengembangan

Hasil tahap pengembangan awal dari website pembelajaran digital didasarkan pada rancangan pada template tahap perencanaan. Visualisasi hasil pengembangan website pembelajaran digital ditampilkan pada gambar 2 .

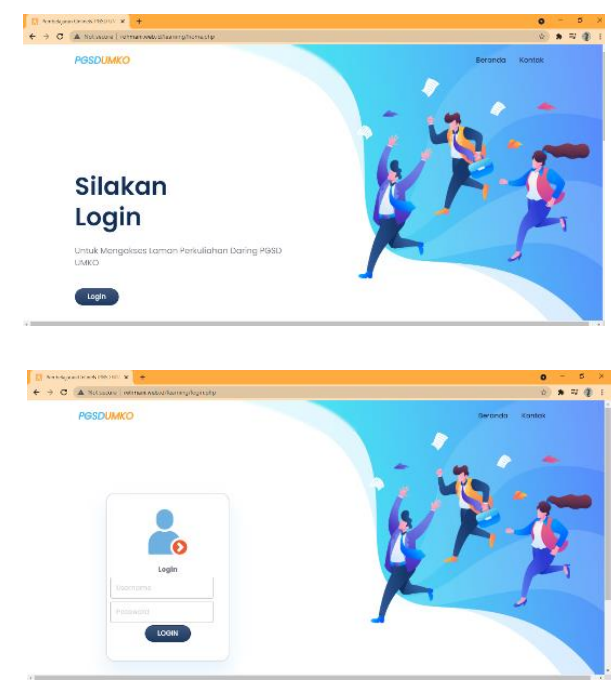

Gambar 2. Halaman login website pembelajaran digital 
Visualisasi halaman utama website pembelajaran digital disajikan dalam gambar 3.

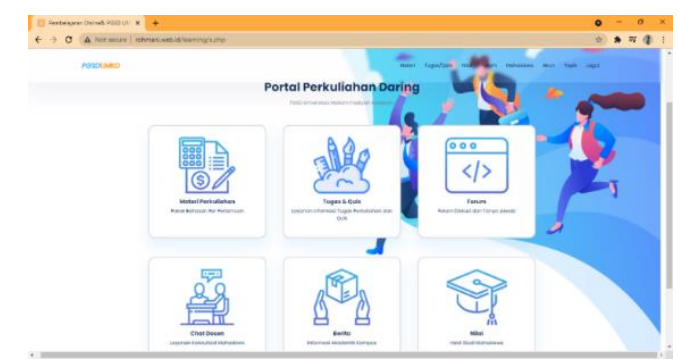

Gambar 3. Halaman utama website pembelajaran digital

4. Hasil Tahap Validasi Desain

Hasil pengembangan Website pembelajaran digital kemudian divalidasi oleh validator guna mengetahui tingkat kelayakan produk sebelum uji coba lapangan sekala besar. Proses validasi meliputi validasi materi oleh ahli materi dan validasi desain media oleh ahli media. Berikut uraian hasil dari validasi media pembelajaran digital.

a. Validasi Produk Media Oleh Ahli Materi Validasi desain website pembelajaran digital oleh ahli materi disajikan dalam tabel 1 . Adapun aspek penilaian terdiri dari uraian materi, cakupan materi, kesesuaian materi, serta kejelasan materi. Berikut ringkasan hasil validasi dari ahli materi.

Tabel 1. Validasi Ahli Materi

\begin{tabular}{lllll}
\hline $\begin{array}{l}\text { Aspek } \\
\text { Penilaian }\end{array}$ & $\begin{array}{l}\text { Skor yang } \\
\text { diperoleh }\end{array}$ & $\begin{array}{l}\text { Skor } \\
\text { Maksimum }\end{array}$ & $\begin{array}{l}\text { Persentase } \\
\text { Skor }(\%)\end{array}$ & Keterangan \\
\hline $\begin{array}{l}\text { Cakupan } \\
\text { Materi }\end{array}$ & 11 & 13 & 84,6 & $\begin{array}{l}\text { Sangat } \\
\text { Baik }\end{array}$ \\
\hline $\begin{array}{l}\text { Keakuratan } \\
\text { Materi }\end{array}$ & 8 & 9 & 88,8 & $\begin{array}{l}\text { Sangat } \\
\text { Baik }\end{array}$ \\
\hline Relevansi & 7 & 9 & 77,7 & Baik \\
\hline
\end{tabular}

Rata-rata validasi desain website pembelajaran digital oleh ahli materi sebesar $82,7 \%$ dan dinyatakan valid karena $\geq 61 \%$.

b. Validasi Produk Media Oleh Ahli Media Validasi oleh ahli media terhadap website pembelajaran digital disajikan dalam tabel 2 dengan rentang nilai tertinggi 4 dan terendah 1. Adapun aspek penilaian meliputi tampilan website, konten, tata bahasa dan interaktifitas. hasil validasi secara lengkap sebagai berikut.

Tabel 2. Hasil Validasi Ahli Media

\begin{tabular}{lcllc}
\hline $\begin{array}{l}\text { Aspek } \\
\text { Penilaian }\end{array}$ & $\begin{array}{l}\text { Skor yang } \\
\text { diperoleh }\end{array}$ & $\begin{array}{l}\text { Skor } \\
\max \end{array}$ & $\begin{array}{l}\text { Persentase } \\
\text { Skor }(\%)\end{array}$ & Ket. \\
\hline Tampilan & 27 & 36 & 75 & Baik \\
\hline Konten & 14 & 20 & 70 & Baik \\
\hline Tata bahasa & 7 & 8 & 87,5 & $\begin{array}{c}\text { Sangat } \\
\text { Baik }\end{array}$ \\
\hline Interaktifitas & 6 & 8 & 75,0 & Baik \\
\hline
\end{tabular}

Rata-rata validasi desain website pembelajaran digital oleh ahli media sebesar $76,87 \%$ dan dinyatakan valid karena $\geq 61 \%$.

c. Validasi Oleh Praktisi dan Teman Sejawat validasi desain website pembelajaran digital oleh praktisi dan teman sejawat disajikan dalam tabel 3. Adapun aspek penilaian terdiri dari tampilan layout website, kejelasan konten, penggunaan bahasa, interaktifitas, uraian materi, cakupan materi, kesesuaian materi serta kejelasan materi. Ringkasan hasil validasi praktisi dan teman sejawat sebagai berikut.

Tabel 3. Hasil Validasi Praktisi dan Teman Sejawat.

\begin{tabular}{|c|c|c|c|c|c|c|c|c|}
\hline No. & $\begin{array}{c}\text { Aspek } \\
\text { Penilaian }\end{array}$ & $\begin{array}{l}\text { Prak } \\
\text { tisi } 1\end{array}$ & $\begin{array}{l}\text { Prak } \\
\text { tisi } 2\end{array}$ & $\begin{array}{l}\text { Prak } \\
\text { tisi } 3\end{array}$ & $\begin{array}{c}\text { Sjwt } \\
1\end{array}$ & $\begin{array}{c}\text { Sjwt } \\
2\end{array}$ & $\begin{array}{l}\text { Total } \\
\text { Nilai }\end{array}$ & Keterangan \\
\hline 1. & Tampilan & 82,5 & 83,6 & 85,4 & 82,9 & 83,6 & 83,6 & Sangat Baik \\
\hline 2. & Konten & 77,6 & 79,7 & 78,5 & 79,4 & 78,8 & 78,8 & Baik \\
\hline 3. & Tata bahasa & 85,6 & 83,6 & 84,6 & 84,2 & 84,5 & 84,5 & Sangat Baik \\
\hline 4. & Interaktifitas & 73,5 & 75,2 & 75,5 & 75,8 & 75 & 75,0 & Baik \\
\hline 5. & $\begin{array}{l}\text { Cakupan } \\
\text { materi }\end{array}$ & 79,4 & 78,5 & 79,6 & 77,7 & 78,8 & 78,8 & Baik \\
\hline 6. & $\begin{array}{l}\text { Keakuratan } \\
\text { Materi }\end{array}$ & 78,4 & 79 & 78,4 & 78,4 & 79,8 & 78,8 & Baik \\
\hline 7. & Relevansi & 76,6 & 77,4 & 75,4 & 76,2 & 78,4 & 76,8 & Baik \\
\hline 8. & $\begin{array}{l}\text { Penyajian } \\
\text { Pembelajaran }\end{array}$ & 85,5 & 86,6 & 84,5 & 86,2 & 84,7 & 85,5 & Sangat baik \\
\hline
\end{tabular}

5. Hasil Tahap Perbaikan Desain

Hasil tahap perbaikan desain meliputi perbaikan desain dan beberapa isi dari website pembelajaran digital sesuai saran dan masukan dari ahli. Tampilan website dibuat lebih menarik dan mudah diakses serta navigasi antar tombol dibuat mengikuti saran ahli media.

6. Hasil Tahap Uji Coba Produk

Uji coba produk dilakukan terhadap 30 mahasiswa PGSD universitas Muhammadiyah 
Kotabumi tanggal 5 Oktober 2020. Mahasiswa yang dipilih memenuhi kriteria diantaranya dari mahasiswa berkemampuan akademis tinggi sebanyak 10 mahasiswa, mahasiswa berkemampuan akademis sedang sebanyak 10 mahasiswa, dan mahasiswa berkemampuan akademis kurang sebanyak 10 mahasiswa. Hasil dari uji coba produk berupa informasi berisi saran dan masukan dari angket yang diisi oleh mahasiswa. Mahasiswa diberikan kebebasan dan tanpa tekanan saat mengisi angket sehingga data hasil uji coba bisa dijadikan panduan dalam tahap selanjutnya. Berikut disajikan beberapa hasil dari uji coba produk yang berupa masukan dan saran dari subjek uji coba pada tabel 4 .

Tabel 4. Saran dan masukan dari subjek uji coba produk

\begin{tabular}{|c|c|c|}
\hline No & Aspek Media & Masukan dan saran \\
\hline 1. & $\begin{array}{l}\text { Kejelasan materi } \\
\text { pembelajaran } \\
\text { digital }\end{array}$ & $\begin{array}{l}\text { Materi sudah disajikan dengan runtut, tetapi ada beberapa } \\
\text { analogi contoh yang sulit dipahami. Lebih memberikan } \\
\text { contoh yang mudah dipahami mahasiswa }\end{array}$ \\
\hline 2. & Teks & $\begin{array}{l}\text { Tek pada materi gaya berat kurang jelas, warnanya terlalu } \\
\text { samar dengan warna background. } \\
\text { Pada contoh soal urutan penyajian materi masih belum jelas, } \\
\text { pelan pelan aja. }\end{array}$ \\
\hline 3. & $\begin{array}{l}\text { Tombol Submit } \\
\text { Tugas }\end{array}$ & $\begin{array}{l}\text { Tombol submit tugas saat diklik terjadi error. Lebih } \\
\text { ditingkatkan lagi agar mahasiswa tidak kesulitan dalam } \\
\text { mengirim tugas }\end{array}$ \\
\hline 4. & Tombol lihat materi & $\begin{array}{l}\text { Tombollihat materi pada pertemuan } 05 \text { tidak dapat diakses. } \\
\text { Materi yang sudah diunduh tidak dapat dibaca harus diubah } \\
\text { dalam bentuk pdf terlebih dahulu baru bisa dibuka. Lebih } \\
\text { dipermudah lagi dalam membuat lampiran materi }\end{array}$ \\
\hline
\end{tabular}

\section{Hasil Tahap Revisi Produk}

Data hasil uji coba terbatas berupa saran dan masukan dari mahasiswa dijadikan acuan dalam merevisi produk dengan tetap berpedoman pada hasil validasi ahli. Hasil revisi produk dilakukan pada materi tertentu yang tidak bertentangan dengan hasil validasi dari ahli. Hanya beberapa perbaikan yang dilakukan dari hasil ujicoba produk, perbaikan yang dilakukan diantaranya pada tombol submit tugas dan tombol lihat materi serta perbaikan format ekstensi file lampiran pada materi menjadi .pdf agar lebih mudah diakses mahasiswa. Tombol submit sedikit diperbesar dan disesuaikan dengan tulisan yang ada didalamnya, sedangkan tombol lihat materi tidak berfungsi karena terdapat kesalahan pengkodingan sehingga harus diperbaiki.

8. Hasil Tahap Uji Coba Pemakaian
Uji coba pemakaian produk
pembelajaran digital di berikan kepada

mahasiswa PGSD Universitas Muhammadiyah Kotabumi dengan jumlah siswa 43 orang dengan tingkat kemampuan akademik yang heterogen. Uji coba pemakaian dilakukan selama satu semester dengan mengikuti rancangan satuan acara perkuliahan (SAP). Tujuan dari uji coba pemakaian adalah untuk mengetahui kelayakan website pembelajaran digital materi IPA kelas tinggi hasil pengembangan. Berikut hasil dari uji coba pemakaian website pembelajaran digital:

a. Data hasil belajar mahasiswa

Data hasil belajar mahasiswa berupa data kognitif yang kemudian digunakan untuk mengetahui efektivitas penggunaan website pembelajaran digital pada perkuliahan Pendidikan IPA kelas tinggi dari hasil pengembangan sebagai media pembelajaran jarak jauh (PJJ). Data diperoleh melalui pretest diawal perkuliahan dan postest mahasiswa diakhir perkuliahan. Berikut hasil belajar mahasiswa dengan menggunakan website pembelajaran digital pada mata kuliah Pendidikan IPA kelas tinggi disajikan pada tabel 5 .

Tabel 5. Hasil pretest dan postest siswa

\begin{tabular}{lll}
\hline Perbandingan & Pretest & Postest \\
\hline Nilai Maksimum & 79,0 & 100,0 \\
\hline Nilai Minimum & 32,0 & 44,0 \\
\hline Rerata Nilai & 62,83 & 82,46 \\
\hline Nilai KKM & 70,0 & 70,0 \\
\hline Siswa yang tuntas & 25 & 37 \\
\hline Siswa yang tidak tuntas & 19 & 6 \\
\hline
\end{tabular}

Hasil pretest dan postest nilai kognitif mahasiswa mengalami kenaikan baik dari nilai maksimum dan nilai minimum. Dilihat dari nilai rerata preetest dan postest mengalami kenaikan sebesar 19,63 atau $12,13 \%$ dengan jumlah siswa yang tuntas sebesar $86,04 \%$ yang artinya telah mencapai tingkat ketuntasan klasikal.

b. Data angket penilaian produk media pembelajaran

Data angket penilaian kepraktisan terhadap website pembelajaran digital disajikan dalam ringkasannya pada tabel 6 sebagai berikut. 
Tabel 6. hasil penilaian website pembelajaran digital

\begin{tabular}{llcl}
\hline No & Aspek penilaian & Perolehan nilai (\%) & Kategori \\
\hline 1. & Dayatarik & 93.9 & Sangat Baik \\
2. $\quad$ Tingkat & 87.9 & Baik \\
$\quad$ Kesulitan & 89.7 & \\
3. $\quad$ Manfaat & $\mathbf{9 0 . 5}$ & Sangat Baik \\
Jumlah Rata-Rata & & \\
\hline
\end{tabular}

c. Saran dan masukan hasil uji coba pemakaian

Hasil uji coba pemakaian produk website pembelajaran digital, didapatkan beberapa saran dan masukan dari angket yang telah diisi mahasiswa setelah menggunakan website pembelajaran digital. Beberapa hasil saran dan masukan hasil uji coba pemakaian produk disajikan dalam tabel 7 sebagai berikut.

Tabel 7 komentar, saran dan masukan hasil uji coba pemakaian

\begin{tabular}{lll}
\hline No & Aspek Media & \multicolumn{1}{c}{ Komentar, Masukan dan saran } \\
\hline 1. & Audio & $\begin{array}{l}\text { Suara pengisi materi diusahakan yang } \\
\text { lebih merdu lagi ya. }\end{array}$ \\
2. & Tampilan website & $\begin{array}{l}\text { Tampilan website menarik dan } \\
\text { dinamis }\end{array}$ \\
3. & Gambar & $\begin{array}{l}\text { Gambarnya mohon diperjelas lagi ya, } \\
\text { masih kurang jelas. }\end{array}$ \\
4. & Kontent & $\begin{array}{l}\text { Materinya lebih menarik saat } \\
\text { disampaikan melalui penjelasan video }\end{array}$ \\
5. & Tombol & $\begin{array}{l}\text { LKS tidak ada nomor halamannya, } \\
\text { Tulisan pada tombol lebih dibuat } \\
\text { kontras dengan warna tombolnya, } \\
\text { agak susah dibaca }\end{array}$ \\
\hline
\end{tabular}

\section{Hasil Tahap Revisi Produk}

Hasil revisi produk website pembelajaran digital yaitu produk akhir website pembelajaran digital yang dapat diakses melalui link http://rohmani.web.id/learning . Perbaikan yang dilakukan pada tahap terakhir lebih berfokus kepada kenyamanan dan kemudahan penggunaan website pembelajaran digital dari masukan dan saran subjek uji coba pemakaian. Adapun beberapa revisi yang dilakukan pada produk media pembelajaran pada tahap akhir meliputi kejelasan warna teks dan warna tombol dan kualitas gambar beresolusi lebih tinggi, dan beberapa pembenaran pada penulisan naskah materi/lampiran materi.

\section{KESIMPULAN}

Pengembangan website pembelajaran digital sebagai alternatif solusi pembelajaran jarak jauh dapat dikembangkan melalui 9 tahap pengembangan mengikuti langkah-langkah yang dijelaskan oleh Sugiyono. Untuk mengetahui kelayakan website pembelajaran digital dilakukan uji coba pemakaian dan uji coba kelayakan dengan subjek yang berbeda dengan tingkat akademis yang heterogen. Website pembelajaran digital hasil pengembangan telah memenuhi syarat kelayakan yang ditunjukkan dari hasil validasi produk sebesar 79,3\%, hasil uji coba produk sebesar 90,5\% dan tingkat efektivitas penggunaan sebesar $86,04 \%$. Kelayakan produk berdasarkan ketiga indikator tersebut menjadikan website pembelajaran digital dapat dijadikan sebagai solusi dari permasalahan yang ada pada pembelajaran jarak jauh terkhusus pada perkuliahan pendidikan IPA kelas tinggi di Prodi PGSD Universitas Muhammadiyah Kotabumi

\section{DAFTAR PUSTAKA}

Bakri, F., Siahaan, B. Z., \& Permana, A. H. (2016). Rancangan Website Pembelajaran Terintegrasi dengan Modul Digital Fisika Menggunakan 3D PageFlip Professional. Jurnal Penelitian \& Pengembangan Pendidikan Fisika, 2(2), 113-118.

Belawati, T. (2019). Pembelajaran online. Jakarta, Universitas Terbuka.

Faisal, M., Hotimah, H., Nurhaedah, N., Nurfaizah, A. P., \& Khaerunnisa, K. (2020). Peningkatan Kompetensi Guru Sekolah Dasar dalam Mengembangkan Bahan Ajar Digital di Kabupaten Gowa. Publikasi Pendidikan, 10(3), 266-270.

Husaini, M. (2017). Pemanfaatan teknologi informasi dalam bidang pendidikan (eeducation). MIKROTIK: Jurnal Manajemen Informatika, 2(1).

John, D. (2020). Coronavirus (COVID-19) and Online Learning in Higher Institutions ofEducation: A Survey of the Perceptions of Ghanaian International Students in China. Online Journal of Communication and Media Technologies, 10(3), 0-9. https://www.ojcmt.net/download/coronavir 
us-covid-19-and-online-learning-in-higherinstitutions-of-education-a-survey-of-the8286.pdf

Kahfi, A. (2020). Tantangan Dan Harapan Pembelajaran Jarak Jauh Di Masa Pandemi Covid 19. Dirasah: Jurnal Pemikiran Dan Pendidikan Dasar Islam, 3(02), 137-154.

Komalasari, R. (2020). Manfaat Teknologi Informasi dan Komunikasi di Masa Pandemi Covid 19. TEMATIK-Jurnal Teknologi Informasi Dan Komunikasi, 7(1), $38-50$.

Nugroho, A. (2012). Pengembangan model pembelajaran jarak jauh berbasis web. Jurnal Transformatika, 9(2), 72-78.

Nur, M. D. M. (2017). Pengaruh Strategi Pembelajaran Fisika Berbasis Website Terhadap Hasil Belajar pada Siswa yang Memiliki Selfregulated Learning (SRL) yang Berbeda. Edcomtech Jurnal Kajian Teknologi Pendidikan, 2(1), 65-76.
Purwanto, H. (2016). Manfaat Penelitian Untuk Perkembangan Gereja. Seminar Nasional Pendidikan Agama Kristen Dan Call for Papers.

Putri, G. K., \& Dewi, Y. A. S. (2019). Pengaruh Model Pembelajaran Jarak Jauh Berbasis Google Classroom. AL-FIKRAH: Jurnal Studi Ilmu Pendidikan Dan Keislaman, 2(1), 60-79.

Rahmawati, D. (2008). Analisis Faktor Faktor yang Berpengaruh Terhadap Pemanfaatan Teknologi Informasi. Jurnal Ekonomi Dan Pendidikan, 5(1).

Riduwan. (2011). Dasar-Dasar Statistik. Alfabeta.

Sugiyono. (2013). Metode Penelitian Kualitatif, Kuantitatif, dan $R \& D$. Alfa Beta.

Sugiyono. (2016). Metode Penelitian Kuantitatif, Kualitatif dan $R \& D$. Alfa Beta. 